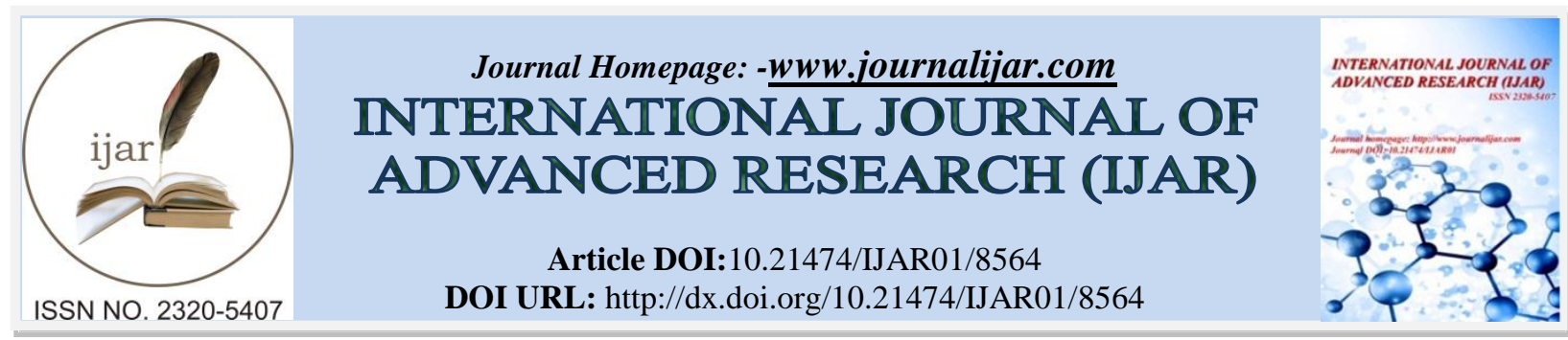

RESEARCH ARTICLE

\title{
IMPACT OF ENTREPRENEURIAL CHARACTERISTICS ON THE ENTREPRENEURIAL ORIENTATION OF SME HOLDERS (REFERRED TO PAMBAHINNA IN BALANGODA DIVISIONAL SECRETARIAT).
}

\section{P. Lankeshwara ${ }^{1}$ and N.M. Wijesekara ${ }^{2}$.}

1. Department of Management and Finance, Faculty of Management, Social Sciences and Humanities, General Sir John Kotelawala Defence University.

2. Department of Economics and Statistics, Faculty of Social Sciences and Languages, Sabaragamuwa University of Sri Lanka.

\section{Manuscript Info}

\section{Manuscript History}

Received: 14 December 2018

Final Accepted: 16 January 2019

Published: February 2019

\begin{abstract}
In the current era of highly volatile business environment, entrepreneurial characteristic is the most crucial factor that affects the entrepreneurial orientation. The main objective of this study was to identify the impact of entrepreneurial characteristics on the entrepreneurial orientation of SME holders. The study has utilized primary data and 143 SME entrepreneurs were selected from Pambahinna in Balangoda Divisional Secretariat, using a structured questionnaire. With the intention of determining the nature and strength of the relationship between the factors of entrepreneurial characteristics and entrepreneurial orientation, five explanatory variables have been studied as need for achievements, locus of control, leadership, risk taking and innovativeness. Descriptive Statistics Analysis, Correlation Analysis and Multiple Regression Model have utilized as the main analyzing techniques. The survey results revealed that among the five entrepreneurial characteristics, only locus of control, leadership, risk taking and innovativeness have shown significant influence for the entrepreneurial orientation and need for achievement is insignificant with the entrepreneurial orientation. Among all the demographic and socio economic factors, innovativeness has emerged as the most important factor for predicting the entrepreneurial orientation and almost all the explanatory variables positively influence for the entrepreneurial orientation. Further, according to the research findings, entrepreneurial orientation of SME holders is at moderate level.
\end{abstract}

Copy Right, IJAR, 2019,. All rights reserved.

\section{Introduction:-}

Entrepreneurship is a process undertaken by an entrepreneur to augment his business interests. It is an exercise involving innovation and creativity that will go towards establishing his or her enterprise. Entrepreneurship is a compose skill, the resultant of a mix of many qualities and traits, which include tangible factors as imagination, readiness to take risks, ability to bring together and put to use other factors of production, capital, labour and land as well as other intangible factors such as managerial skill, ability to mobilize scientific and technological advances

Corresponding Author:-N.M. Wijesekara.

Address:-Department of Economics and Statistics, Faculty of Social Sciences and Languages, 926 
etc. In practice, entrepreneurs have historically altered the direction of national economies, industries or markets. They have invented new products and developed organizations and the means of production to bring them to market according to their characteristics.

Characteristics of successful entrepreneurs have also been well documented. While there is no agreement among the scholars as to the number and labels of these characteristics. In general include desire for responsibility, preference for moderates risk and confidence in personal success, desire for immediate feedback, high level of energy, sufficient emotional stability, objective approach to interpersonal relationships, low need for status and a comprehensive awareness of total environment (Olm \& Eddy, 1985). Feather (1988) only refers to successful owner/managers as those who have entrepreneurial characteristics. According to Cunningham and Lischeron(1991), successful owner/managers have been identified with a personal value type referred as entrepreneurial. The characteristics of an entrepreneur differ from entrepreneur to entrepreneur, even though, the characteristics of an entrepreneur that contribute to success are the result of his achievement motivation.

Several studies have investigated the influence of entrepreneur characteristics on their orientation by utilizing different approaches. As far back as in the 1950s, researchers began linking personality characteristics and entrepreneurship by examining personality characteristics that could determine who was more likely to become a successful entrepreneur (Byers, Kist \&Sutton, 2007). McClelland (1961) for example asserted that entrepreneurs possessed certain personality characteristics than non-entrepreneurs. While on the other hand, Carter, Gartner, Shaver and Gatewood (2003), acknowledged the only main difference between entrepreneurs and non-entrepreneurs is that entrepreneurs want to be in control of their own destiny. This control is indicative and draws attention to the fact that, "there is no set of behavioral attributes that allow us to separate entrepreneurs from non-entrepreneurs". They argue that anyone wishes to become successful needs to achieve and that all achievement elements are found not only in entrepreneurs but also in all successful people. Drucker (2007) in concurrence, stated that "It is not a personality trait; everyone who can face up to decision making can learn to be an entrepreneur and to behave entrepreneurially". Additionally, literature studies on entrepreneurship portray successful entrepreneurs as individuals who possess a personal quality that enables them to make decisions that have far reaching effects in conditions of uncertainty. The ability to make such decisions can be achieved in some people through training, while in others, it is inborn.

In the 1980s and 1990s, it was conducted research on personality characteristics and socio-cultural backgrounds of successful entrepreneurs were conducted (Byers, 2007). Other studies were geared towards defining entrepreneurial characteristics and a research debate emerged on whether these characteristics are innate or can be developed (Rasheed \& Rasheed, 2003). Today, in this twenty-first century, studies on the characteristics of entrepreneurs have incorporated a number of variables; psychological attributes, personality, attitudes and the behavior of the entrepreneur (Rasheed \& Rasheed, 2006). However, a research by Timmons and Spinelli (2009) encompassing an analysis of more than 50 studies on entrepreneurial characteristics found a consensus around six general characteristics (commitment and determinations; leadership; opportunity obsession; tolerance of risk, ambiguity and uncertainty; creativity, self - reliance and ability to adapt; and motivation to excel), which most authors agree are amongst the distinctive qualities of an entrepreneur.

\section{Research problem:-}

According to entrepreneurial theories, an entrepreneur would have specific set of characteristics; as risk taking, innovating etc. However, in reality these precise characteristics would not be always inbuilt by small business entrepreneurs.

It is a curial task to survive in doing business in Sri Lanka for more than eight years (NHREP, 2011). Statistics show that, out of all the business operating 50\% of them tend to fail (Forbes, 2012). SME holders in Pambahinna are no exception for that. This is due to many significant reasons such as lack of relevant knowledge, funds and ability to endure. An empirical study carried out by Hung, Orphan and Cynthia (2008) state that the key success factors of a business is influenced by the dominant traits of the entrepreneurs.

Therefore, this study attempts to identify:-

What is the impact of owner's entrepreneurial characteristics on entrepreneurial orientation? 


\section{Research Objectives:-}

1. Assess the level of entrepreneurial orientation of SME holders

2. Examine whether there is an impact of entrepreneurial characteristics on entrepreneurial orientation

3. Determine which key entrepreneurial characteristics are essential for entrepreneurial orientation

\section{Methodology:-}

In the present study, primary data was utilized and the data was collected usinga structured questionnaire. A structured questionnaire has been designed to collect the data from entrepreneurs by using likert scale as strongly agree, agree, neutral, disagree and strongly disagree. The sample consisted of 143 SME holders selected from Pambahinna in Balangoda Divisional Secretariat Division in accordance with the Morgan approach of sample selection through the purposive sampling technique. Descriptive Statistics Analysis, Correlation Analysis and Multiple Regression Model were utilized as the main analyzing techniques.

The model is conceptualized as follows.

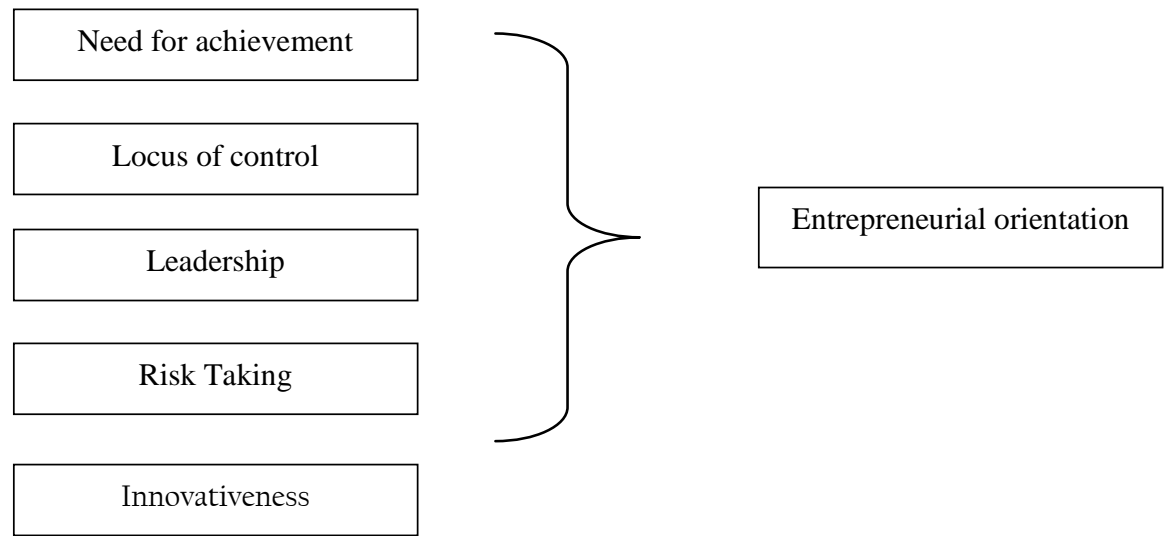

Figure 1:-Conceptual Framework

Source:-Muhammad Azam Farooq, 2012

The study was operationalized as follows:-

Table 1:-Operationalization

\begin{tabular}{|c|c|c|c|}
\hline Variables & Indicators & Measures & Question Number \\
\hline Need for Achievement & $\begin{array}{ll} & \text { Open to new ideas } \\
\checkmark & \text { Mind setting to achieve goals } \\
\checkmark & \text { Anticipate future possibilities } \\
\checkmark & \text { Feedbacks as discouragement }\end{array}$ & Likert scale & 06-09 \\
\hline Locus of control & $\begin{array}{ll}\checkmark & \text { Can determine own destiny } \\
\checkmark & \text { Willing to accept both positive } \\
\text { and negative consequences of } \\
\checkmark & \text { own decisions } \\
\checkmark & \text { Believe that success lies in our } \\
\checkmark & \text { own effort } \\
\text { Believe that success is a product } \\
\text { of luck and fate }\end{array}$ & Likert scale & $10-13$ \\
\hline Leadership & $\begin{array}{l}\checkmark \text { Build communication process to } \\
\text { make people say what in mind } \\
\checkmark \\
\text { Demonstrate to peers that I } \\
\text { believe trust is the foundation for } \\
\text { success } \\
\checkmark \\
\text { Reward employees on good } \\
\text { performance } \\
\checkmark \\
\text { Facilitate the development of joint } \\
\text { vision }\end{array}$ & Likert scale & $14-17$ \\
\hline
\end{tabular}




\begin{tabular}{|c|c|c|c|}
\hline Risk taking & $\begin{array}{ll} & \text { Prefer being low paid employee } \\
\text { with job security } \\
\checkmark & \text { Willing to take a low risk for a } \\
\text { sure rate of return } \\
\checkmark & \begin{array}{l}\text { Do not fear investing money on a } \\
\text { project whose risk is calculated. }\end{array}\end{array}$ & Likert scale & $18-20$ \\
\hline Innovativeness & $\begin{array}{ll}\checkmark & \text { Know my customer } \\
\checkmark & \text { Ability to identify innovative } \\
\text { approaches } \\
\checkmark \quad \text { Anticipate changes and perceive } \\
\text { trends } \\
\checkmark \quad \text { Anticipate future consequences of } \\
\text { current situations }\end{array}$ & $\begin{array}{l}\text { Likert } \\
\text { scale }\end{array}$ & $21-24$ \\
\hline $\begin{array}{l}\text { Entrepreneurial } \\
\text { Orientation }\end{array}$ & $\begin{array}{ll}\checkmark & \text { Self-orientation } \\
\checkmark & \text { Risk taking abilities } \\
\checkmark & \text { Innovativeness } \\
\checkmark & \text { Visualization skills }\end{array}$ & $\begin{array}{l}\text { Likert } \\
\text { scale }\end{array}$ & $25-28$ \\
\hline
\end{tabular}

\section{Results and Discussion:-}

Reliability Test (Cronbach's Alpha):-

Within this study, to measure the entrepreneurial characteristics and entrepreneurial orientation several questions were applied and each question has 5 scales from strongly disagree to strongly agree.

Results of the Reliability Test:-

Table 2:-Reliability Statistics

\begin{tabular}{|l|c|c|}
\hline Dimension & Cronbach's Alpha & Number of item \\
\hline Need for achievement & 0.749 & 4 \\
\hline Locus of control & 0.604 & 4 \\
\hline Leadership & 0.643 & 4 \\
\hline Risk taking & 0.708 & 3 \\
\hline Innovativeness & 0.723 & 4 \\
\hline Entrepreneurial orientation & 0.793 & 4 \\
\hline
\end{tabular}

Source:-Sample Survey, 2018

According to the results of reliability statistics, Cronbach's Alpha value of each variable is greater than 0.6. Therefore, it is possible to conclude that all the questions are reliable to measure the explanatory variables and the response variable (entrepreneurial orientation).

\section{Descriptive Analysis:-}

Assess the Level of Entrepreneurial Orientation:-

To assess the level of entrepreneurial orientation, Descriptive Analysis of mean and standard deviation were used.

For the interpretation purposes of the mean, following levels were used.
1. $1 \leq \mathrm{X}<2.5$
Low level
2. $2.5 \leq X<3.5$
Medium level
3. $3.5 \leq \mathrm{X}<5$
High level

Table 3: -Mean and Standard Deviation of Entrepreneurial Orientation

\begin{tabular}{|l|c|c|}
\hline Indicators & Mean & Standard Deviation \\
\hline Entrepreneurial Orientation & 2.48 & 0.926 \\
\hline
\end{tabular}

Source:-Sample Survey, 2018 
The mean and standard deviation of entrepreneurial orientation are recorded as 2.48 and 0.926 respectively. It implies that the entrepreneurial orientation is at moderate level and it can be dispersed around the mean by 0.926 .

\section{Correlation Analysis:-}

With the intention of identifying the influential factors for the entrepreneurial orientationand determining the nature and strength of the relationship between the explanatory variables and response variable Pearson's Correlation procedure has been utilized under this section.

Table 4:-Results of the Correlation Analysis

\begin{tabular}{|l|c|c|}
\hline Dimension & Correlation Coefficient & P-value \\
\hline Need for achievement & 0.046 & 0.582 \\
Locus of control & 0.475 & 0.000 \\
Leadership & 0.703 & 0.000 \\
Risk taking & 0.730 & 0.000 \\
Innovativeness & 0.746 & 0.000 \\
\hline
\end{tabular}

Source:-Sample Survey, 2018

According to the results of the Correlation Analysis, locus of control, leadership, risk taking and innovativeness are significantly correlated with the entrepreneurial orientation, as $\mathrm{P}$ values of those three variables are less than 0.05 significance level. Need for achievement is insignificant with entrepreneurial orientation due to higher $\mathrm{P}$ value. When concerning the correlation coefficients; locus of control, leadership and risk taking have recorded moderate level of positive correlation with the entrepreneurial orientation while innovativeness strongly correlated with the entrepreneurial orientation.

Regression Analysis:-

Table 5:-Model Summary:-

\begin{tabular}{|l|r|}
\hline Figure & Value \\
\hline $\mathrm{R}$ & 0.939 \\
$\mathrm{R}^{2}$ & 0.881 \\
Adjusted R & 0.877 \\
Standard Error of Estimation & 0.324 \\
\hline
\end{tabular}

Source:-Sample Survey, 2018

R-square tells how much of the variation of the dependant variable is explained by the independent variables. According to the results of the model summary, from the total variation of entrepreneurial orientation $88.1 \%$ has explained by the locus of control, leadership, risk taking and innovativeness. Then only $19.9 \%$ of variance of entrepreneurial orientation is explained by other influencing factors, which are not covered by this study.

The adjusted R square of the study is 0.877 and it indicates that the higher portion of the model $(87.7 \%)$ is fit for the population.

Analysis of variance (ANOVA):-

Table 6:-Results of the Analysis of Variance

\begin{tabular}{|l|c|c|c|c|}
\hline Model & Sum of Squares & Degree of Freedom & F & Significant \\
\hline Regression & 107.200 & 4 & 254.942 & 0.000 \\
Residual & 14.507 & 138 & & \\
Total & 121.706 & 142 & & \\
\hline
\end{tabular}

Source:-Sample Survey, 2018

The above table 6 has revealed that 121.706 from total sum of squares, 107.200 can be explained by regression and 14.507 is explained by residual value. Hence, the model is statistically significant as relatively large portion of model is explained by regression. As per the above information, $\mathrm{P}$ value is 0.000 . Therefore, the statistical evidence of the model supports to reject the null hypothesis ( $\mathrm{P}$ value $<0.05)$. It concludes that the overall fitted model can be applied significantly for predicting the entrepreneurial orientation. Summary of the Coefficient Table 
Table 7:-Results of the Coefficient Table

\begin{tabular}{|l|c|c|c|c|c|}
\hline Predictor & Coefficients $(\beta)$ & Standard Error & Beta & T & Sig. \\
\hline Constant & 1.008 & 0.116 & & 18.726 & 0.000 \\
\hline Locus of Control & 0.301 & 0.031 & 0.297 & 9.661 & 0.000 \\
\hline Leadership & 0.433 & 0.035 & 0.469 & 12.416 & 0.000 \\
\hline Risk Taking & 0.135 & 0.060 & 0.109 & 2.260 & 0.025 \\
\hline Innovativeness & 0.504 & 0.047 & 0.443 & 10.632 & 0.000 \\
\hline
\end{tabular}

Source:-Sample Survey, 2018

According to the coefficients table, locus of control, leadership, risk taking and innovativeness were significant, as $\mathrm{P}$ values of those variables are less than 0.05 significance level.

Based on the results of the regression analysis, the equation of the regression can be depicted as follows.

$\mathrm{Y}=1.008+0.301 \mathrm{X} 1+0.433 \mathrm{X} 2+0.135 \mathrm{X} 3+0.504 \mathrm{X} 4$

Where,

$\mathrm{Y}=$ Entrepreneurial Orientation

$\mathrm{X} 1 \mathrm{l}$ Locus of Control

X2 = Leadership

$\mathrm{X} 3$ = Risk Taking

$\mathrm{X} 4$ = Innovativeness

$B$ values represents the extent to which the value of the independent variable contributes to the variance of the dependent variable.

The constant hasa unstandardized $\beta$ value of 1.008. It indicates the value of the entrepreneurial orientation, when all of the independent factors remain constant.

$B$ value of locus of control suggests that, if locus of control component is increased by one unit, entrepreneurial orientation will increase by 0.301 units when all of other variables remain constant and similarly the coefficient of the leadership indicates, when it is increased by one unit, entrepreneurial orientation will also increase by 0.433 units.

Risk taking and innovativeness have also shown positive relationship with entrepreneurial orientation. When risk taking component is increased by one unit, entrepreneurial orientation will increase by 0.135 units and innovativeness leads to increase entrepreneurial orientation by 0.504 units.

Innovativeness has the highest $\beta$ value of 0.504 indicating it as the most influential factor for the entrepreneurial orientation of SME holders. Locus of control, leadership, risk taking and innovativeness positively influence for the entrepreneurial orientation.

The correlation analysis and the regression analysis together revealed that locus of control, leadership, risk taking and innovativeness has a positive and significant impact on entrepreneurial orientation while need for achievement is insignificant with entrepreneurial orientation.Pereira(2010) elaborated the ideal characteristics of an entrepreneur has Creativity, Leadership, Goal Orientation, Innovation, Team Building, Risk Taker, Dynamism, Problem Solver and Commitment.

The research article also underlines that "do something better" and finally "do something differently" Kirton (1976). Bonnstetter(2012) conducted an independent research on entrepreneurs out of which five key elements were found as Persuasion, Leadership, Personal Accountability, Goal orientation and interpersonal skills. Gomez (2013) stated that in order an entrepreneur to be successful he needs to possess certain traits such as being self- critical- able to adjust according to the situation by understanding the strengths and weaknesses. Another important trait is being creative and innovative, being optimistic and high self- esteem to establish clear goals and being patient. Vecchio (2003) sees entrepreneurs as a combination of the following five traits which are the propensity to take risks, need of achievement, need for autonomy, self- efficacy and internal locus of control.

Leadership plays a vital role in the survival and success of entrepreneurial ventures (Moore and Buttner, 1997). Timmons and Spinelli (2008) after conducting a study at the Harvard business school revealed that motivation to 
excel was the single most important factor in the long-term successes of businesses. From the above, it becomes imperative for these factors to be enhanced by means of nurturing SMEs success and long-term surviving.

With regards to risk taking, Hisrich and Peters (2002) argue that empirically no conclusive causal relationships has been found with regards to risk and entrepreneurs and that the risk-taking propensity trait does not form an important part of the research on entrepreneurial characteristics. Macko and Tyszka (2009) reckon that the risk connected with running a business venture is related to the skills of the entrepreneur.

When compared to the past empirical studies, present study also illustrated the same idea, as according to the findings all the selected entrepreneurial characteristics positively influence for the entrepreneurial orientation.

Innovativeness could be identified as the most crucial factor for predicting the entrepreneurial orientation in the present study and it is further confirmed by Holt(1992), as his study explained thatboth creativity and innovativeness become the most necessary conditions to become a successful entrepreneur.

\section{Conclusions:-}

The main objective of this study was to examine whether there exist an impact of entrepreneurial characteristics on entrepreneurial orientation of SME holders. With the intention of determining the nature and strength of the relationship between the factors of entrepreneurial characteristics and entrepreneurial orientation, five explanatory variables have been studied and among those only locus of control, leadership, risk taking and innovativeness have shown significant influence for the entrepreneurial orientation and need for achievement is insignificant with the entrepreneurial orientation. Among all the demographic and socio economic factors, innovativeness has emerged as the most important factor for predicting the entrepreneurial orientation and almost all the explanatory variables positively influence for the entrepreneurial orientation. Further, according to the research findings, entrepreneurial orientation of SME holders is at moderate level.

\section{Recommendations:-}

For developing characteristics such as creativity, self-reliance and ability to adapt and innovation, they must engage in reading books in a variety of fields; joining professional groups; attending professional meetings and seminars and devote time to pursue natural curiosities. This is because successful creations are generally found by information gathering. Owners must have a proper and clear Vision /Mission to achieve goals in an effective way and owners have to develop a democratic leadership style for the survival. Leadership characteristics in entrepreneurs should be developed through experimental learning, social interaction learning, training in leadership knowledge and skills development, motivation, communication skills and team working.

\section{Further Research:-}

The present study concerned only SME holders in Pambahinna in Balangoda Divisional Secretariat Division. But regarding with other industries, entrepreneurial characteristics may vary. Therefore, in future, when carrying out a research all other industries in other areas should also be under taken. Further, a large sample would have been more representative.

This study focused only on the impact of need for achievement, locus of control, leadership, risk taking and innovativeness on entrepreneurial orientation. But there are other factors which influence on entrepreneurial orientation. A detailed study would provide an insight to determine the most crucial factor that influences entrepreneurial orientation.

\section{References:-}

1. Bonnstetter, B.J. (2012) The Skills That Make an Entrepreneur. Harved Business view.

2. Byers, T., Kist, H., \&Sutton R.I. (2007) Characteristics of the Entrepreneur: Social Creatures, Not Solo Heroes. The Handbook of Technology Management, Boca Raton: CRC Press LLC.

3. Byers, T., Kist, H., \&Sutton R.I. (2007) Characteristics of the Entrepreneur: Social Creatures, Not Solo Heroes. The Handbook of Technology Management, Boca Raton: CRC Press LLC.

4. Carter, N. M., Gartner, W. B., Shaver, K.G., \& Gatewood, E.J. (2003) The career reasons of nascent entrepreneurs. Journal of Business Venturing.

5. Cunningham, J., \& Lischeron, J. (1991) Defining Entrepreneurship. Journal of Small Business Management. 
6. Drucker P. (2007) The Practice of Management. Classic Collection Paperback.

7. Farooq, M.A. (2012)A Study of Psychological and Non Psychological Factors of Owner Influencing Entrepreneurial Orientation: Evidence from Khyber Pakhtunkhwa. Pakistan.

8. Feather, N. T. (1988) Understanding unemployed people's job search behaviour, unemployment experience and well- being: A comparison of expectancy-value theory and self-determination theory.British Journal of Social Psychology.

9. Gomez, M. (2013) Successful entrepreneur's traits. (online) Available at:- http://www.anentrepreneur.com/being-n an-entrepreneur/90-successful-entrepreneurs-traits-part-4

10. Holt, D.H. (1992) Entrepreneurship: New Venture creation. Prentice - Hall, India.

11. Olm, A. L. K. L., \& Eddy, G.G. (1985) Entreperneurship: Reasearch in Quest of a paradiam. Ballinger, Cambridge.

12. Pereira, J. (2010) Entrepreneurship. Available (online) at: http://www.slideshare.net/jud20anna/entrepreneurship

13. Timmons, J. A., \& Spinelli, S. (2009) New Venture Creation: Entrepreneurship for the 21st Century. New York: McGraw-Hill/Irwin.

14. Vecchio, R.P. (2003) Entrepreneurship and leadership: common trends and common threads. Human Resource Management Review. 